\title{
The methods of pathos expression in patriotic songs
}

\author{
Olga Kobzhitskaya ${ }^{1}$, Alexandra Koshel $^{1 *}$, and Nina Adilkhanian ${ }^{1}$ \\ ${ }^{1}$ Irkutsk State University, Institute of philology, foreign languages and media communications, \\ Faculty of foreign languages, Department of the Orientalism and Regional studies of APR, Irkutsk, Russia
}

\begin{abstract}
The article concerns the phenomenon of pathos, which is considered a category in rhetoric, and the methods of its expression in Chinese patriotic songs. There has been a specific kind of pathos in patriotic songs, a heroic one. The lyrics and tunes of such songs contain the considerable extent of influence on a listener, and, therefore, they cause deep patriotic feelings in his or her heart. Tropes defined the figurative meaning of words and phrases are able to express solemnity and inspiration inherent in patriotic songs. There have been national, cultural, and linguistic features in tropes analyzed in the article.
\end{abstract}

\section{Introduction}

Pathos (in Greek means «excitation», «passion», «inspiration», «misery») is a rhetorical category defining the exalted way of feeling expression, a specific rhetorical method for making speech more expressive and convincing. The notion of pathos is inseparable from rhetoric, which is a branch of science that deals with eloquence. Aristotle is considered a person who facilitated the development of rhetoric significantly. According to Aristotle, rhetoric is an ability to find the ways of persuasion in different fields. The main function of rhetoric, which is stipulated in his specific monograph «The rhetoric», is its focus on the excitation of any opinion. In accordance with «The poetic», which is another Aristotle's study, rhetoric is a scope of thought and lore that can be achieved by a word. In other words, it is impossible to inflame an opinion and gain knowledge without the excitation of emotions [1].

There have been several crucial categories in rhetoric that are ethos, pathos, and logos. The categories had been put forward by Aristotle in the IV century B.C.E., and hitherto they are cornerstones of the construction of public performance. The author of «Rhetoric theory» Y.V. Rozhdestvenskiy notes that ethos is conditions that a speech recipient offers the creator of such speech. In turn, pathos is an intention, a thought of a speech creator that is intended to develop a particular topic in front of the recipient. Logos defines verbal measures used by a creator of speech when performing the main idea of the speech [2]. Another scholar, S.F. Ivanova, claims that pathos is a form of speech expression that corresponds to a situation and the idea of a statement, and, as a consequence, it contributes to the understanding of the sense of such statement [3]. All rhetoric scholars believe that the three categories clearly enough divide argumentation principals in rhetoric, and they are equally important in terms of the creation of plain and persuasive speech.

\section{Rhetorical pathos and its features}

Amid many methods to understanding pathos as a psychic and emotional influence on people, there should be distinguished rhetorical pathos. The main idea of the method is that attention is supposed to be emphasized on the interaction between classical pathos and an ideologue's stance.

During his performance, a speaker does not only try to affect the public by the extent of the pathos of his speech, but he also tries to offer some ways to solve a particular issue. As a result, the public expresses its considerable interest in that speech [4]. Within that approach, A.A. Volkov distinguishes four types of rhetorical pathos, such as heroic, romantic, sentimental, naturalistic [4].

The object of analysis in the article is Chinese patriotic songs themselves with heroic pathos inherent in them. In turn, the subject of study is the ways of pathos expression in patriotic songs. The topic is relevant due to several reasons. First, music has a great impact on Chinese political and social fields. Second, it is important to find out the influential potential of Chinese songs and, subsequently, to figure out specific ways and means that are connected with this influence. Finally, lately, scholars are interested in the ethnical and cognitive aspects of the interaction between languages and cultures. It allows us to consider pathos expression ways as a separate study field, because they were not considered independently before. The sources of the article are Chinese military and patriotic songs. In total, there have been 50 songs.

There are some features in terms of the expression of pathos in a song, which consists of a tune and lyrics. The main figures of speech used for pathos expression are tropes that increase the extent of speech emphasis. 
According to the notion stipulated in the vocabulary of D.E. Rozental, a trope is a speech expression in which a word or a phrase are used in figurative meaning in order to achieve a better extent of expressiveness and brightness [5].

Notably, the learning of figures of speech is examined by both Russian Chinese scholars [6, 7, 8, 9, $10,11]$. In the articles of the mentioned above scholars, the use of tropes is considered as an instrument for metaphorizing an image in Chinese phraseological units [12]. Therefore, the role of tropes in Chinese patriotic songs is to be extremely fascinating as a topic of study.

Among persuasion, coercion, and suggestion, which are considered as ways to affect an individual, pathos related to feelings is connected with the means of convincing. In that sense, patriotic songs embody heroic pathos, which usually has an exalted style. It is an effective way, especially when it comes to appealing to a nation. The core of such pathos is heroism that contained in song lyrics and ready to strive for freedom and to stand for the independence of a country.

\section{The use of rhetorical pathos in music}

In terms of the embodiment of heroic pathos in songs, it is also important to consider music. Musical rhetoric is supposed to have a maximum reflection in terms of the sense as of a text, so as of particular words. That is why, when creating, composers apply musical figures of speech, which increase the extent of emotional influence on a listener. The main purpose is to draw attention, conquer, and captivate people's feelings, make people become sensitive and surprised .

The musical heritage of China has a long-term history. In particular, it is more than 2.5 thousand years from the first collection of oral art «Shih Ching» and «The book of songs» that were written in the 9-6 centuries B.C.E. When appealing to his students, Confucius quoted the classical text of the mentioned above books: Why don't you learn songs? Songs can affect people as a compulsion. In songs, you can find useful and bright examples, they teach us how to communicate and help us expressing resentment. In addition, they contribute to serving our parents from one hand and facilitate obeying the government from another one [13].

Another scholar, G.G. Kolomoytz, believes that music in Ancient China was considered not only as a kind of art but as a humane existence rule and as an inseparable part of people's lifestyle. The regulatory function of music corresponded to the notion of harmonic coexisting human communities with the world of nature, space, stars, the Sun, the Moon, and with a great sole milky way [14].

Patriotism, which is devotion and love toward your homeland and your nation, is closely adjacent to heroism. Furthermore, patriotism cannot exist without heroism, because heroism is considered the highest form of patriotism. The phenomenon of patriotism with its deep historical roots can be understood by every social organized person. The core of heroism and patriotism is serving not private interests but social ones. The connotation of that is performing such actions that demand a person to be brave and ready to sacrifice himself.

In Chinese, the word patriotism 爱国主义 makes the following sense: 《爱国主义是指个人或集体的一 种积极和支持的态度，集中表现为民族自尊心和民 族自信心, 为保卫祖国和争取祖国的独立富强而献 身的奋斗精神. 《爱国主义是对国家的爱或忠实的 思想; 爱国者的美德和行动》. Patriotism is an active and steady stance of a particular person or a community that is known for sacrificing in the wake of national dignity, willingness to defend a country and strive for its independence. Patriotism is love and devotion to the state; it is a trait and behavior inherent in patriots. Every Chinese is ready to forsake family thriving in order to be attended in the army in the wake of the prosperity and security of the state.

The unusual patriotism of the Chinese nation can be traced within the entire history of China. During historical hardship, there have been written plenty of songs. In particular, patriotic songs had the greatest impact on the spirit of the nation [15]. As a national liberation movement had been growing against Japanese invaders, the popularity of songs had gained its maximum in the 1930-s. One of the most notable books of that period was «The march of volunteers»义 勇军进行曲 written in 1935 for the film «The children of a thunderstorm». The lyrics were come up with by Tian Han, while the author of the music was Nie Er. The main idea of the film was momentum to resistance against Japanese aggression. The prototype of the lyrics was the military songs 红歌 (in Chinese means literally «red songs») of the volunteers of the '30s who fought in the northeastern front when the aggression of the Japanese invaders had been increasing. Subsequently, the march had become a national anthem of the People's Republic of China and was adopted in 1949. Despite the decision of writing a new national anthem text, it was eventually canceled in 1982 during the 5th session of the National People's Congress of the 5th convening [16].

According to data related to the history of the creation of national anthems, often their lyrics and music were written by authors in a surge of patriotism. It is not a coincidence that the authors of anthems were marked as «geniuses of one night». Due to the above circumstances, «The march of volunteers» along with its heroic pathos could not be replaced by another song as a Chinese national anthem.

Taking into consideration the analysis of the use of tropes, let's take a look at the ways of expression pathos in Chinese patriotic songs. In the lyrics of patriotic Chinese songs, tropes primarily include hyperboles, metaphors, reinterpretations, and comparisons.

In the song 《红军不怕远征难》 《The Red Army is not afraid of the hardship of a distant campaign», there 
have been used two types of hyperbole: 夸张 narrowing and widening ones:

红军不怕远征难 The Red Army is not afraid of the hardship of a distant campaign.

万水千山只等闲。[Conquer] the thousands of rivers and the thousands of mountains - [to her] it is not a big deal.

五岭逶迤细浪 Jumping on five winding mountain ranges, just like on little waves.

乌蒙磅磚走泥丸。Climbing Umengshan mountain, just like climbing clay balls [17].

Concerning the role of hyperbole, Chinese scholars have found common ground with Russian researchers. In particular, in Chinese science, it is also stated that other tropes are not as strong as hyperbole in terms of an emotional extent. Even whenever an author refrains from real facts and numbers, hyperbole is still considerably perceived by a recipient and embodies in his heart such strong feelings that the author himself can have.

In the song «A revolutionary is forever young» 《革 命人永远是年轻》 there has been used a strong comparison 强喻:

革命人永远是年轻。A revolutionary is forever young.

他好比大松树冬夏长青。Forever-green pines are no match for him.

他不怕风吹雨打, He is not afraid of trouble,

他不怕天寒地冻, He is not afraid of cold.

他不摇也不动 Without any hesitation.

永远挺立在山顶 He stands straight on the top of the mountain [17].

In «A praising Homeland song》《歌唱祖国》 there have been laid out the following dominant concepts: a five-star red flag, the Yellow River and the Yangtze river, prosperity, power, a beloved homeland. The obvious comparison used in the song is 明喻:

我们团结友爱坚强如钢。Our cohesion and friendship are as durable as steel.

In the song «The Orient is becoming more scarlet» 《东方红》 with the help of the explicit comparison 明 喻 the communist party resembles the Sun:

共产党像太阳 照到哪里哪里亮。The communist party is like the Sun - a place where it is shining is always bright.

In order to express the importance of Mao Tzedun and his role in the destiny of China, it is common to use personifications and implicit comparisons:

中国出了个毛泽东。China gives us Mao Tzedun as a present.

他为人民谋幸福 呼儿咳呀，他是人民大救星。

He aspires to the happiness of the nation, and he is a saving nation's star [17].

Let's take a look at other personification examples:

东方你就呀个红, The Oriental, you became scarlet

太阳你就呀个升。The Sun, you have risen.
In the song «A spring story» 《春天的故事», using personification, there is stressed the conviction of Chinese people in the supremacy and uniqueness of China.

啊, 中国, 中国, Oh, China, China

你展开了一幅百年的新画卷, You have unfolded a new scroll-picture within the last 100 years

捧出万紫千红的春天。You are exalting diverse spring [17].

Let's provide more examples of reinterpretation. It is another trope that is used to replace a word or a phrase, and in which there have been described the substantial features of the notion (take a look at Maklakova T. B. Figures of speech, the source No.8 mentioned earlier).

龙的国土 《A dragon's land»-China.

Foreigners commonly describe China as «a great dragon of the Oriental», while Chinese people consider themselves as the descendants of the dragon [18].

天下都快乐 - the entire Celestial Empire is rejoicing (the Celestial Empire means the entire population of China). In this example, the author uses metonymy, which is another kind of trope.

The Celestial Empire 天下 is a popular name of China that was come up with in the Zhou Period (the XI - III centuries B.C.E.). The arrival of the ethnonym 天下 meant that the process of the ethnogenesis of Han and the conflation of united ethnos was complete.

打败美国野心狼 to eliminate an «American dictator» - to destroy the US army.

人民战士驱虎豹 Nation's warriors are expelling tigers and leopards - means «to expel enemies».

In Chinese, the primary figures of speech embodied the image of an enemy, backstabber, and corrupt person are the following lexemes: «tiger», «leopard», «fox». According to N.L. Adilhanyan's stance, «those cognitive lexemes are entirely suitable for a deep archetypal opposition «friend or foe», and they develop it in the mythological dimension of collective consciousness and the picture of a Chinese people's world» [19].

家里盘着两条龙是长江与黄河呀 《Our home» is being entangled by «the two dragons» - the Yellow River and the Yangtze river («our home» is China itself).

我们都有一个家名字叫中国。Everyone has «the sole home» that is called China.

In the song «Love my China» 爱我中华, a homeland image is represented by 56 Chinese nations, and the Great Wall of China:

都说长城两边是故乡。Everyone is claiming that the Great Wall of China is a homeland.

你知道长城有多长? Do you know what is the length of it?

它一头挑起大漠边关的冷月, From one side, it ascends to the cold month of wilderness,

它一头连着华夏儿女的心房。From the other side, it connects the hearts of the sons and daughters. 
你要问长城在哪里, You are going to ask where is the wall.

就在咱老百姓的 心坎上。 It is in the hearts of the nation [17].

The Great Wall of China is a key cultural symbol of China. Furthermore, it is a leitmotif in the Chinese national anthem:

起来!

不愿做奴隶的人 Get up, everybody who has no desire to become a slave!

把我们的血肉筑成我们新的长城。We will build a new Great wall from our flesh and blood [16]. In the example above, the author applied a metaphor.

\section{Conclusion}

Thus, since we have considered the ways of pathos expression in Chinese songs, it is time to make conclusions. The lyrics of Chinese patriotic songs have been constructed with the help of the wide use of tropes that increase emotional influence on a listener and make songs sound specifically. The inspiration and pathos of songs can be achieved by appealing to value concepts. The concepts are considered not only as a carrier of lore and appraisal but as methods for appealing to the historical heritage of a nation and to the symbolic potential of signs. In terms of concepts, the pathos of Chinese songs is based primarily upon patriotism, which is considered a valuable and emotional dominant. Patriotism, in turn, is elaborated in the following components: heroism, youth, force, the power of defenders, the cohesion of a nation, happiness, the salvation of a nation, supremacy, uniqueness of China, sacrificing and serving to a nation.

\section{References}

1. G.Z. Apresyan, The art of eloquence ( Publishing house of MSU, Moscow, 1972)

2. U.V. Rozhdestvensiy, Rhetoric theory ( Dobrosvet, Moscow , 1997)

3. S.F. Ivanova, The specific features of public speech (Znanie, Moscow, 1978)

4. A.A. Volkov, The basics of rhetoric: university textbooks (Academicheskiy project, Moscow, 2003)

5. D.E. Rozental, M.A. Telenkova, Dictionaryhandbook of linguistic terms (Astrel, Moscow , 2001)

6. V.I. Gorelov, The stylistic of modern Chinese (Prosveshenie, Moscow, 1979)

7. M.N. Kozhina, The stylistics of Russian ( Prosveshenye, Moscow, 1993)

8. T.B. Maklakova, Figures of speech (ISLU, Irkutsk, 2012)

9. S.A. Hahalova, Metaphor in the aspects of language, mindset and culture (ISLU, Irkutsk, 2011)
10. 王德春, 陈汝东, 对外汉语修辞学 (广西教 育出版社，2000 年)

11. 陈望道, 修辞学发凡 (上海教育出版社, 1997 年)

12. I.V. Voycehovich, The practical phraseology of modern Chinese (AST: Vostok - Zapad, Moscow, 2007)

13. I.I. Semenenko, Confucius. I believe in antiquity ( Respublica, Moscow, 1995)

14. G.G. Kolomiec, Some aspects of a philosophical thought about music in Ancient China: a status and purpose in terms of anthroposocial overview, OSU bulletin, 7, 181, 2009)

15. C.R. Kuular, The characteristic of the tropes of a song genre (based on the examples of patriotic songs) (Molodoy Ucheniy, 16, 409 (2017)

16. O.M. Gotlib, The linguistic and country studies of China. Textbook (Muravey, Moscow , 2004)

17. Best patriotic songs. URL: http://lizhi.yjbys.com/gequ/459611.html (2019).

18. L.G. Vikulova, The basics of intercultural communication. Practical book (AST: AST Moscow: Vostok-Zapad, 2008)

19. N.L. Adilhanyan, The representation of the image of a corrupt person in Chinese media discourse (Gotlib readins: Asia-Pacific region in terms of global developing, Publishing house of ISU, Irkustk, 12 (2017) 